\title{
AERODYNAMIC STABILITY OF BRIDGES WITH VARIOUS LEVELS OF STRUCTURAL DAMPING
}

\author{
Olga Poddaeva*, Pavel Churin
}

University Research and Production Laboratory for Aerodynamic and Aero-Acoustic Testing of Building Structures, National Research Moscow State University of Civil Engineering

Yaroslavskoye Shosse, 26, Moscow, Russia

*E-mail: poddaevaoi@gmail.com

\begin{abstract}
Introduction: Structural damping is one of the most important parameters affecting the aerodynamic stability of bridge structures. Purpose of the study: We aimed to assess the effect that structural damping of a bridge structure has on its stability in a wind current. Methods: In the course of the study, we performed experimental studies of the aerodynamic stability in typical girder bridge structures (with two and four main girders) with different levels of structural damping, facilitated by a unique experimental unit: Large Research Gradient Wind Tunnel, courtesy of the National Research Moscow State University of Civil Engineering (NRU MGSU). Results: The results of the experimental studies show that, despite the general trend towards the decrease in the amplitude of bridge span structure oscillations as the structural damping level increases, the dependence between these parameters is nonlinear. When providing R\&D support in the design of real-life structures, in case it is necessary to increase the aerodynamic stability of the superstructure by increasing the level of structural damping (changing the type of joints in structural elements, using mechanical damping devices), it is recommended to conduct experimental studies in wind tunnels to assess the effectiveness of a given solution.
\end{abstract}

\section{Keywords}

Bridge structure, structural damping, wind tunnel, experimental studies, sectional model.

\section{Introduction}

In the modern world, experimental studies of the aerodynamic stability of large-span bridge structures are an integral part of bridge design. It is very difficult to overestimate the importance of such studies, given the number of accidents involving bridge structures that occurred due to wind impact (Bas and Catbas, 2021; Maystrenko et al., 2017; Tan et al., 2020). In the Russian Federation, testing in wind tunnels is regulated by the following standards: Regulations SP 35.13330.2011 "Bridges and Culverts" and Regulations SP 296.1325800.2017 "Buildings and Structures. Accidental Actions". The main methods for conducting such studies are full-scale modeling (Argentini et al., 2020; Miyata et al., 1992), studies with sectional models (Cermak, 2003; Diana et al., 2013; Reinhold et al., 1992), as well as numerical modeling in specialized software systems (Ageev et al., 2021; Diana and Omarini, 2020; Li et al., 2017). They are the subject of many works by Russian and foreign researchers, as well as of a number of regulatory documents (Highways England, 2020; National Research Council of Italy. Advisory Committee on Technical Recommendations for Construction, 2008).

Among others, the methodology for conducting experimental studies on dynamically similar sectional models is described in the scientific, technical, and regulatory literature in most detail and most comprehensively (Poddaeva et al., 2018; Wardlaw, 1980). The main similarity criteria, in this case, are the following: the Cauchy and Newton numbers (correspondence between the model's and the real object's distribution of masses and moments of inertia); the Scruton number (correspondence between the model's and the real object's logarithmic decrement of oscillations); and the Strouhal number (correspondence between the model's and the real object's frequency characteristics).

One of the most significant research insights is the dependence of the bridge span oscillation amplitude on the velocity of the wind flow at different angles of attack.

If experimental studies detect an unlimited increase in the amplitude of oscillations, this is likely to be caused by one of the phenomena of aerodynamic instability found unacceptable under the Regulations SP 35.13330.2011 and SP 296.1325800.2017, namely galloping, divergence or flexural-torsional flutter (Kazakevich, 2021; Solovyev, 2016). In this case, the most effective solution to the problem is to change the wind flow around the superstructure by making changes to the superstructure design (using deflectors, fairings, etc.) (SP 296.1325800.2017; Nagao et al., 1993; 
Wardlaw, 1992).

When oscillations have a narrow velocity range (meaning that when the velocity increases, the oscillations stop), we can talk about the appearance of vortex excitation (Kazakevich, 2021). Here, the maximum value of the oscillation amplitude is important; it must be compared with the maximum permissible value of the vertical deflection of the bridge span. Despite the effectiveness of aerodynamic damping methods, in this case, designers often resort to increasing structural damping without changing the shape of the bridge span's cross-section. This can be linked to a change in the design features of the respective structure, such as changing the type of connection from welded to ordinary bolted, which increases the level of structural damping from 0.02 to 0.05 . The main question, in this case, is the following: how significant is the drop in the oscillation amplitude going to be? What is even more important to know is the effect that the value of structural damping has on the oscillation amplitude of the bridge span when using different types of mechanical damping devices. The required mass of counterweights and other parameters of additional dampers directly depend on this.

\section{Subject, tasks, and methods}

As the target of our study, we chose one of the most common types of bridge structures: girder bridges with two and four girders (Figures 1-2).

For the purposes of this study, we used a unique experimental unit, the Large Research Gradient Wind Tunnel by the National Research Moscow State University of Civil Engineering (NRU MGSU), in a specialized test bench for static and dynamic tests of building structures.

The methodology for experimental studies of bridge structures' aerodynamic stability in sectional models is described in detail in the scientific and technical literature (Brownjohn and Choi, 2001; Diana et al., 2015). The main task of dynamic tests is to determine the amplitude of bridge span oscillations at various wind flow velocities and angles of attack. As measuring equipment, we used the RAS-T contactless laser displacement sensors by WayCon, which are included in the State Register of Measuring Instruments. The flow velocity in the wind tunnel was recorded with a Pitot-Prandtl tube and a differential pressure gauge.

The main requirement for the model is that it must retain geometric similarity and ensure that its distribution of masses and moments of inertia is consistent with the corresponding parameters of the real object (the Cauchy and Newton numbers mentioned in the introduction). Besides, the model must be as rigid as possible. This is necessary to maintain Scruton number similarity since metal spans with welded joints have a specific minimum level of structural damping. The frequency parameters of the real object are modeled with spring suspensions of a specialized test bench (Figure 3). The sensors are aimed at markers located in the corners of the model, making it possible both to determine the amplitude of the oscillations and to classify their mode.

The level of structural damping is measured with the free damped oscillation method. When subjected to a pulsed external load, the model begins to oscillate, while the sensors record its oscillogram (Figure 4). This oscillogram is analyzed in the software package. The rate of oscillation amplitude reduction is determined by the relative dissipation of energy. The corresponding value is the value of the logarithmic decrement.

The level of structural damping was adjusted with the help of special flexible inserts in the spring suspensions of the specialized test bench.

\section{Results and discussion}

Tables 1-2 show the dynamic parameters of the models obtained during bench tests.

Table 1. Correlations between the model and the real object (Model No. 1)

\begin{tabular}{|c|c|c|c|c|}
\hline \multirow{2}{*}{$\begin{array}{c}\text { Frequencies in the real object and the } \\
\text { model }\end{array}$} & Oscillation mode & Real object & Model & Velocity scale U* \\
\cline { 2 - 5 } & Bending & $0.48 \mathrm{~Hz}$ & $5.22 \mathrm{~Hz}$ & 6.43 \\
\hline
\end{tabular}

Table 2. Correlations between the model and the real object (Model No. 2)

\begin{tabular}{|c|c|c|c|c|}
\hline & Oscillation mode & Real object & Model & Velocity scale $\mathbf{U}^{*}$ \\
\hline \multirow{2}{*}{$\begin{array}{c}\text { Frequencies in the real object and the } \\
\text { model }\end{array}$} & Bending & $0.596 \mathrm{~Hz}$ & $6.1 \mathrm{~Hz}$ & 6.8 \\
\cline { 2 - 5 } & Torsion & $1.36 \mathrm{~Hz}$ & $12.15 \mathrm{~Hz}$ & 7.8 \\
\hline
\end{tabular}


Figure 1. Cross-section of the bridge (Model No. 1)

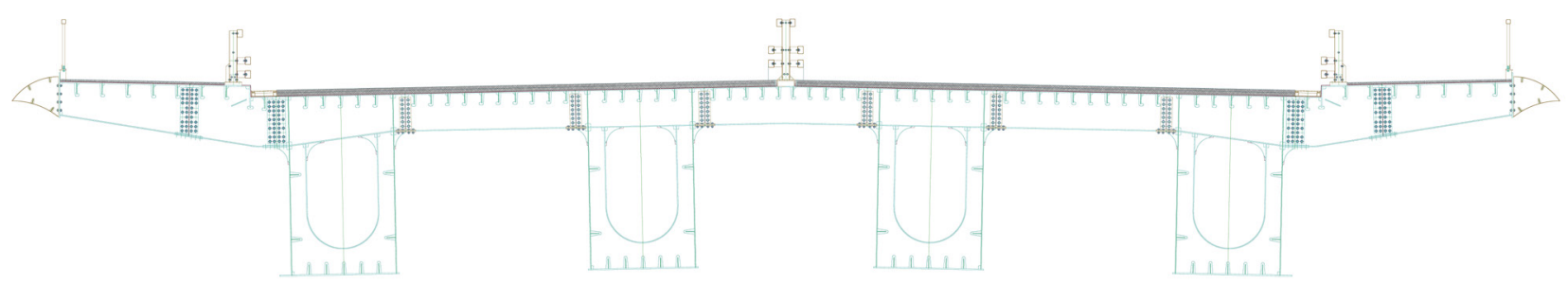

Figure 2. Cross-section of the bridge (Model No. 2)

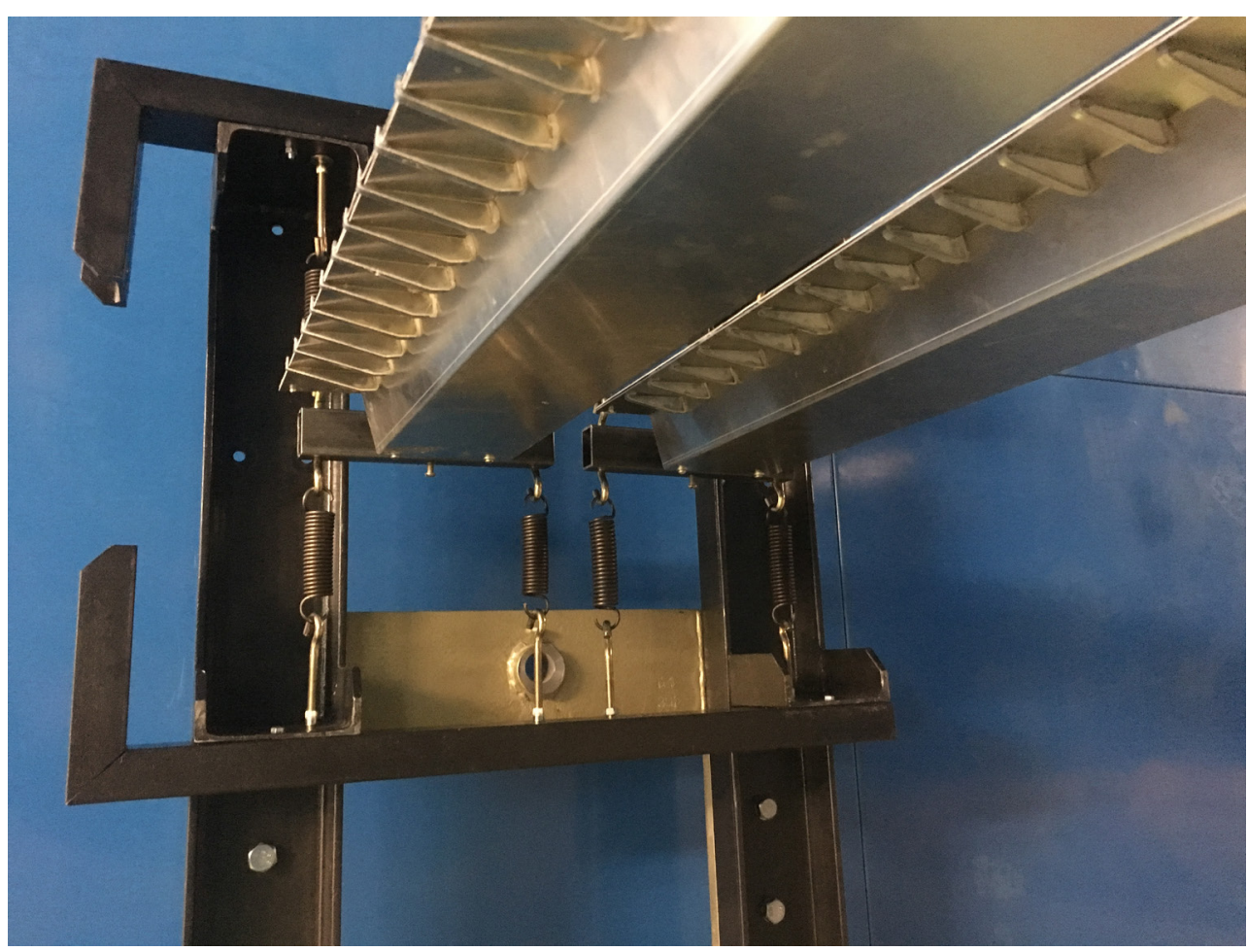

Figure 3. Spring suspensions of the specialized test bench 


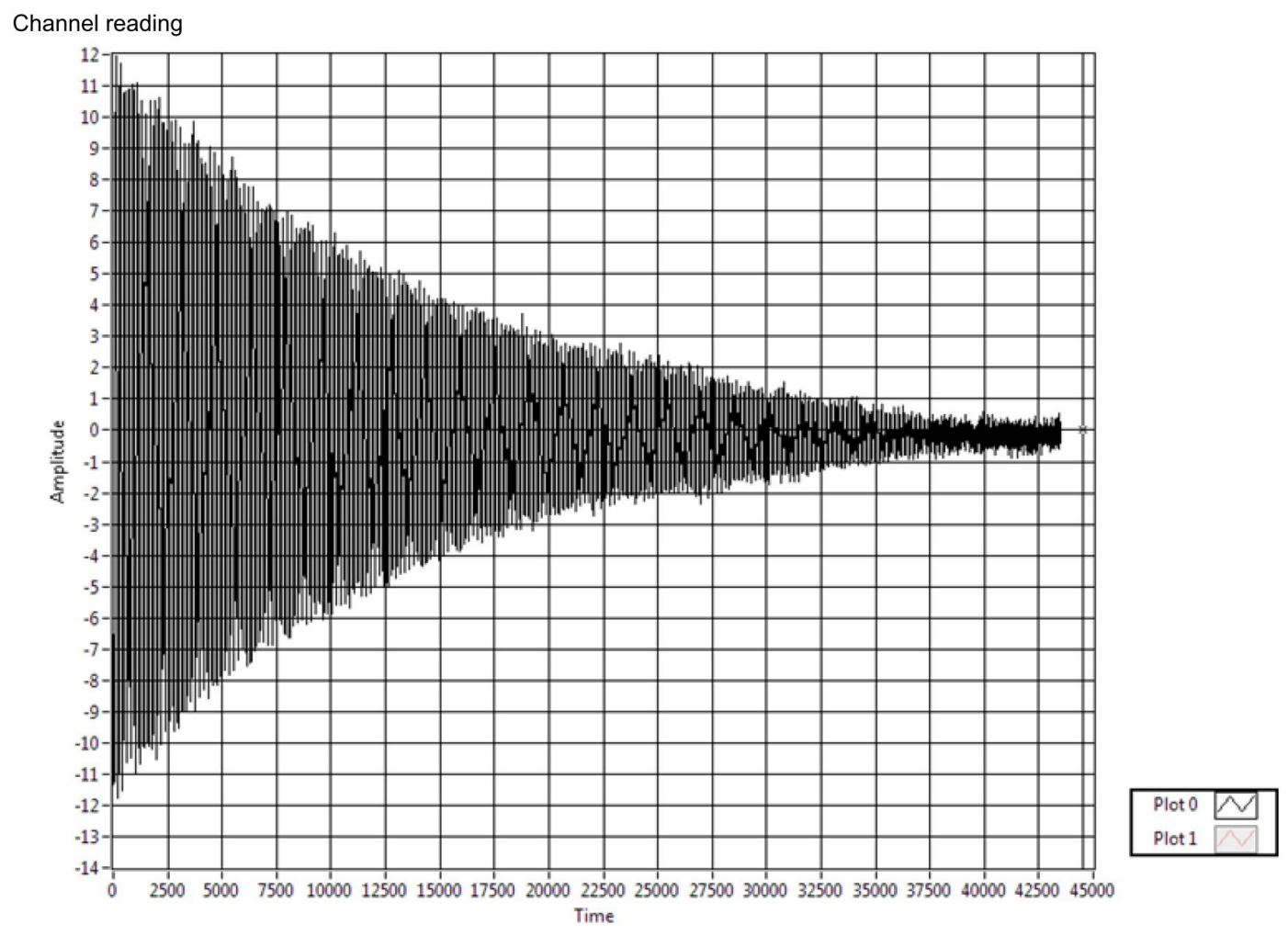

Figure 4. Oscillogram of the model's oscillations

The studies were carried out at the following levels of structural damping: 0.03, 0.045, 0.055, 0.07 . The research results are presented as graphs that show the bridge span oscillation amplitude's dependence on the velocity of the wind flow.

As the most illustrative material, we selected those wind flow angles of attack where the phenomenon of span vortex excitation was detected. In this case, the oscillation frequency of the structure corresponds to the natural oscillation frequency recorded at the preliminary stage of the studies (Tables 1-2).
Figures 5-6 show the results for model No. 1 at the following wind flow angles of attack: $-5^{\circ}$ (downward flow) and $+5^{\circ}$ (upward flow).

Figures 7-8 show the results for model No. 1 at the following wind flow angles of attack: $-3^{\circ}$ (downward flow) and $+3^{\circ}$ (upward flow).

By analyzing the experimental study results, we obtained the ratio of the increase in structural damping $(\Delta \delta, \%)$ to the corresponding decrease in the maximum oscillation amplitude $(\Delta \mathrm{A}, \%)$ for different models at different angles of attack $(\alpha)$.

Table 3. Ratio of the increase in structural damping $(\Delta \delta, \%)$ to the corresponding decrease in the maximum oscillation amplitude $(\Delta \mathrm{A}, \%)$ for different models at different angles of attack $(\alpha)$

\begin{tabular}{|c|c|c|c|c|c|c|}
\hline \multicolumn{7}{|c|}{ Model No. 1} \\
\hline$\alpha,{ }^{\circ}$ & \multicolumn{3}{|c|}{-5} & \multicolumn{3}{|c|}{5} \\
\hline$\Delta \delta, \%$ & 33 & 45 & 57 & 33 & 45 & 57 \\
\hline$\Delta \mathrm{A}, \%$ & 12 & 39 & 66 & 17 & 39 & 69 \\
\hline \multicolumn{7}{|c|}{ Model No. 2} \\
\hline$\alpha,{ }^{\circ}$ & \multicolumn{3}{|c|}{-3} & \multicolumn{3}{|c|}{3} \\
\hline$\Delta \bar{\delta}, \%$ & 33 & 45 & 57 & 33 & 45 & 57 \\
\hline$\Delta \mathrm{A}, \%$ & 6 & 39 & 70 & 19 & 44 & 59 \\
\hline
\end{tabular}




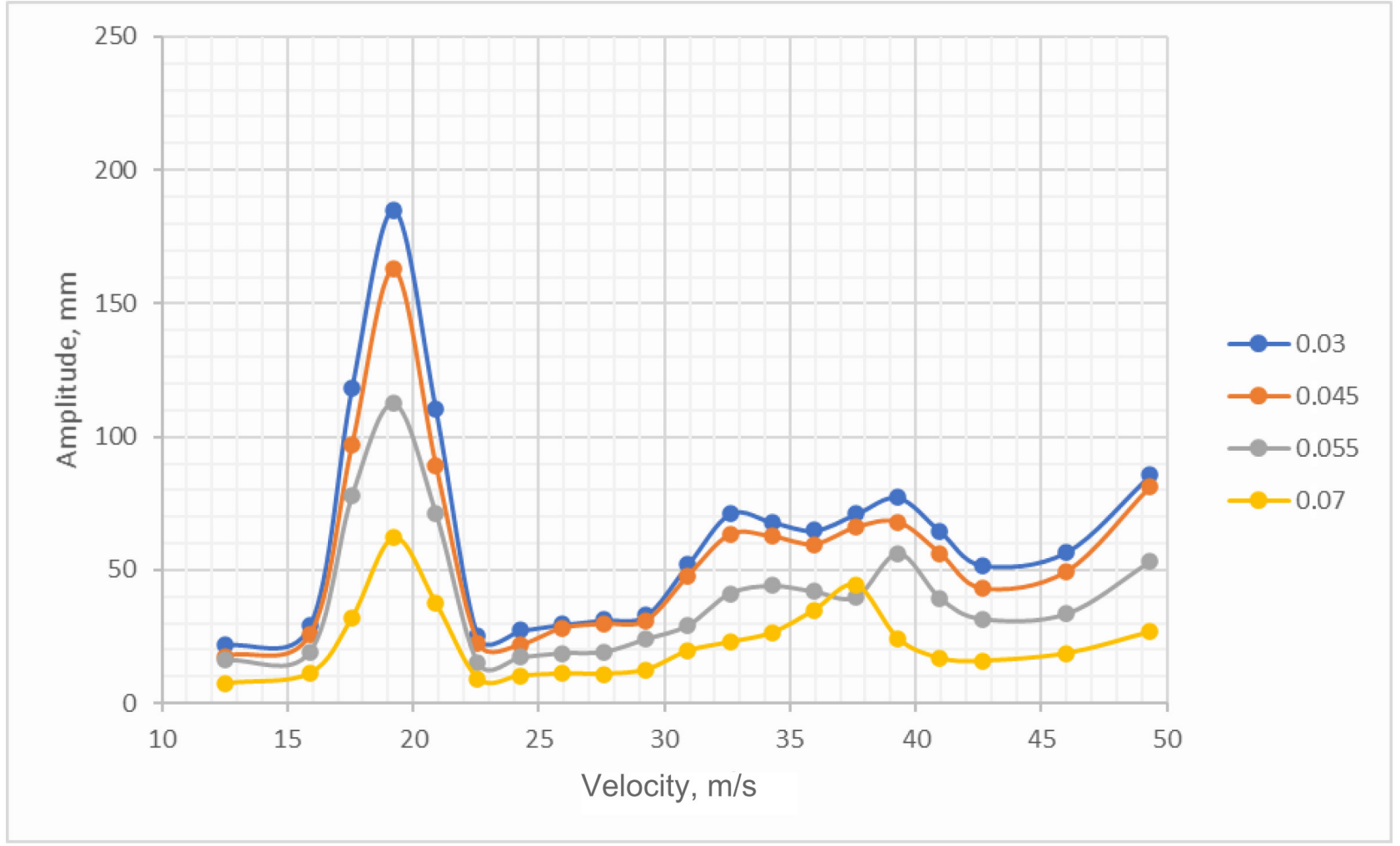

Figure 5. Oscillation amplitude's dependence on the wind flow velocity in the model at an angle of attack of $-5^{\circ}$

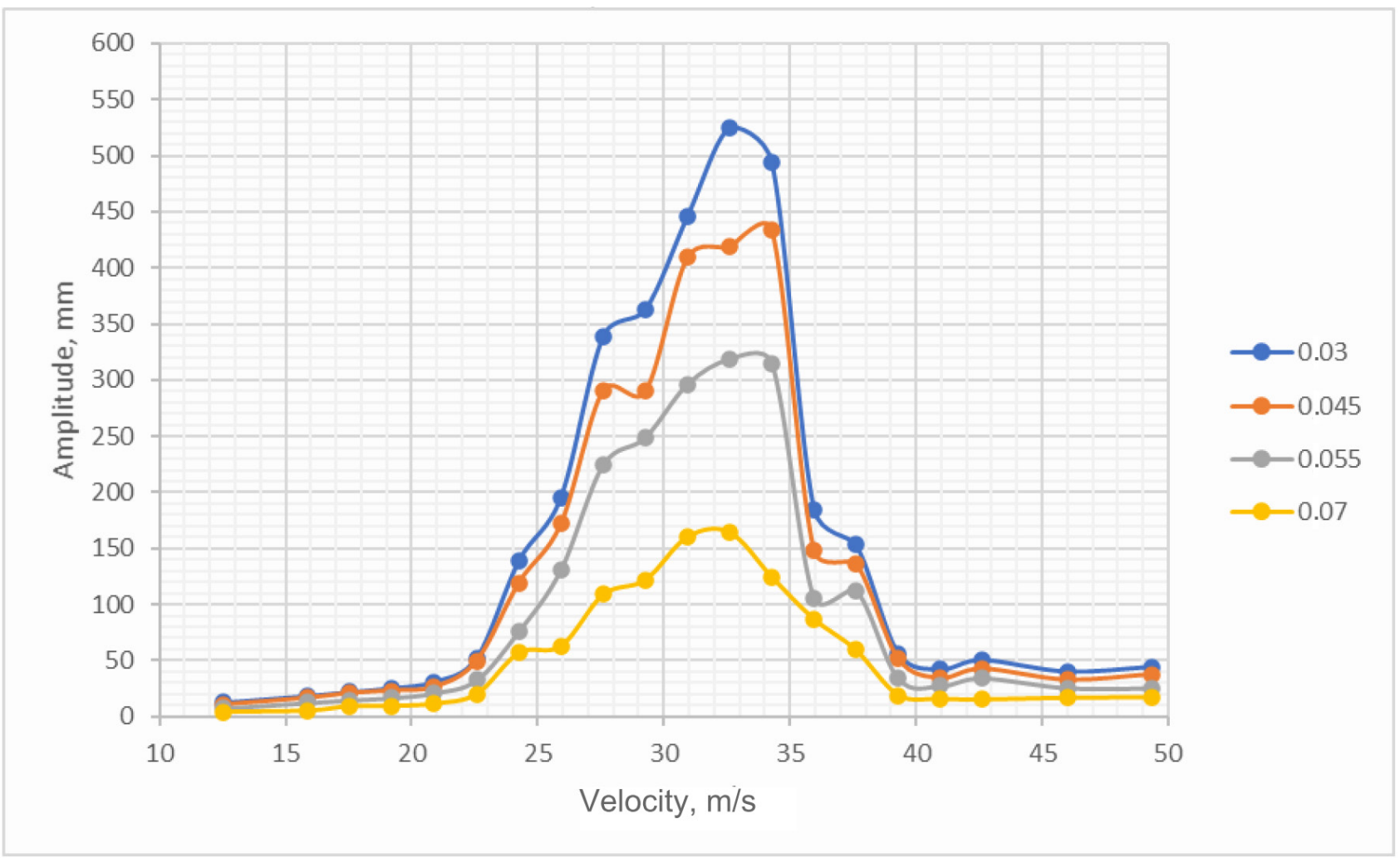

Figure 6. Oscillation amplitude's dependence on the wind flow velocity in the model at an angle of attack of $+5^{\circ}$ 


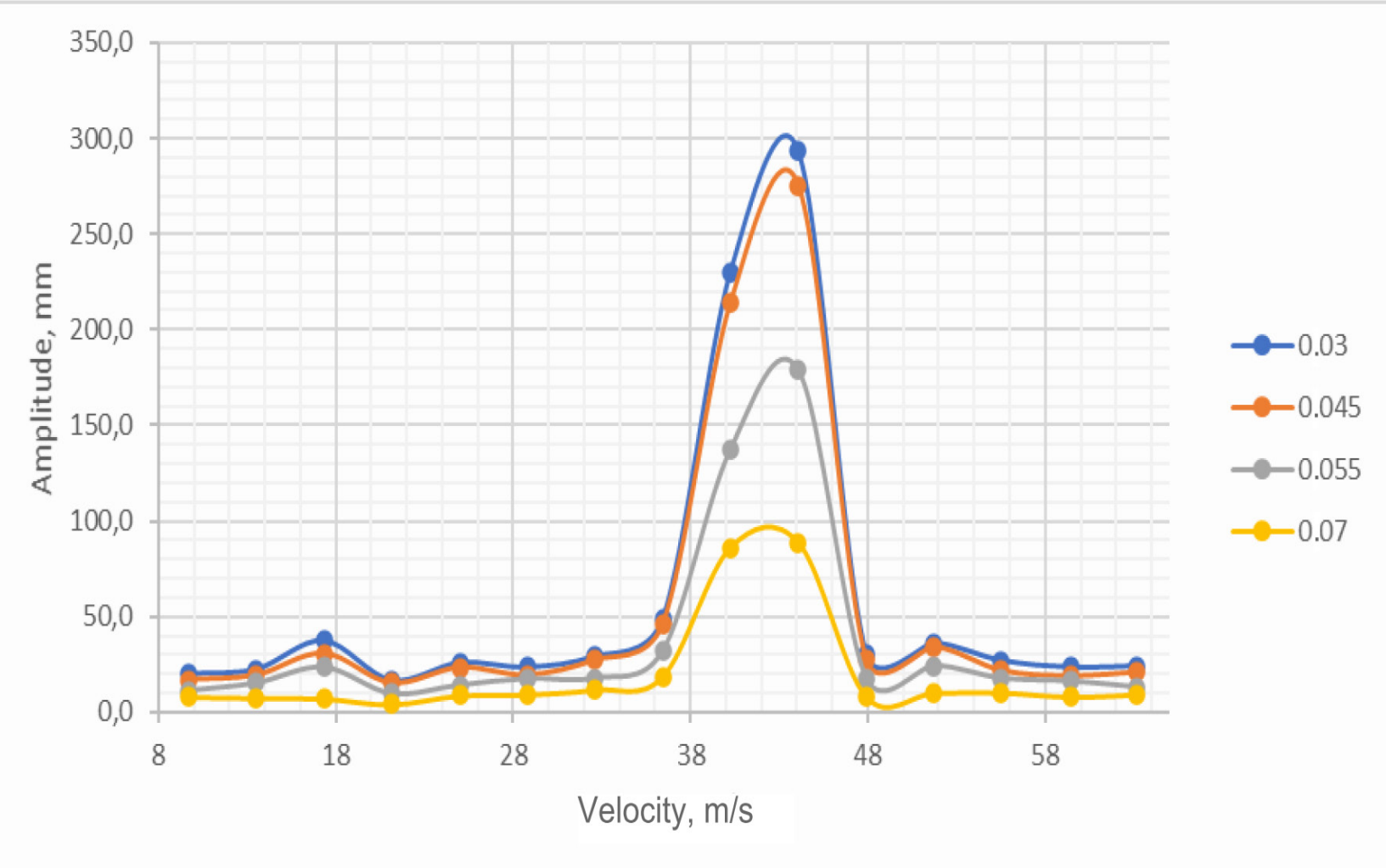

Figure 7. Oscillation amplitude's dependence on the wind flow velocity in the model at an angle of attack of $-3^{\circ}$

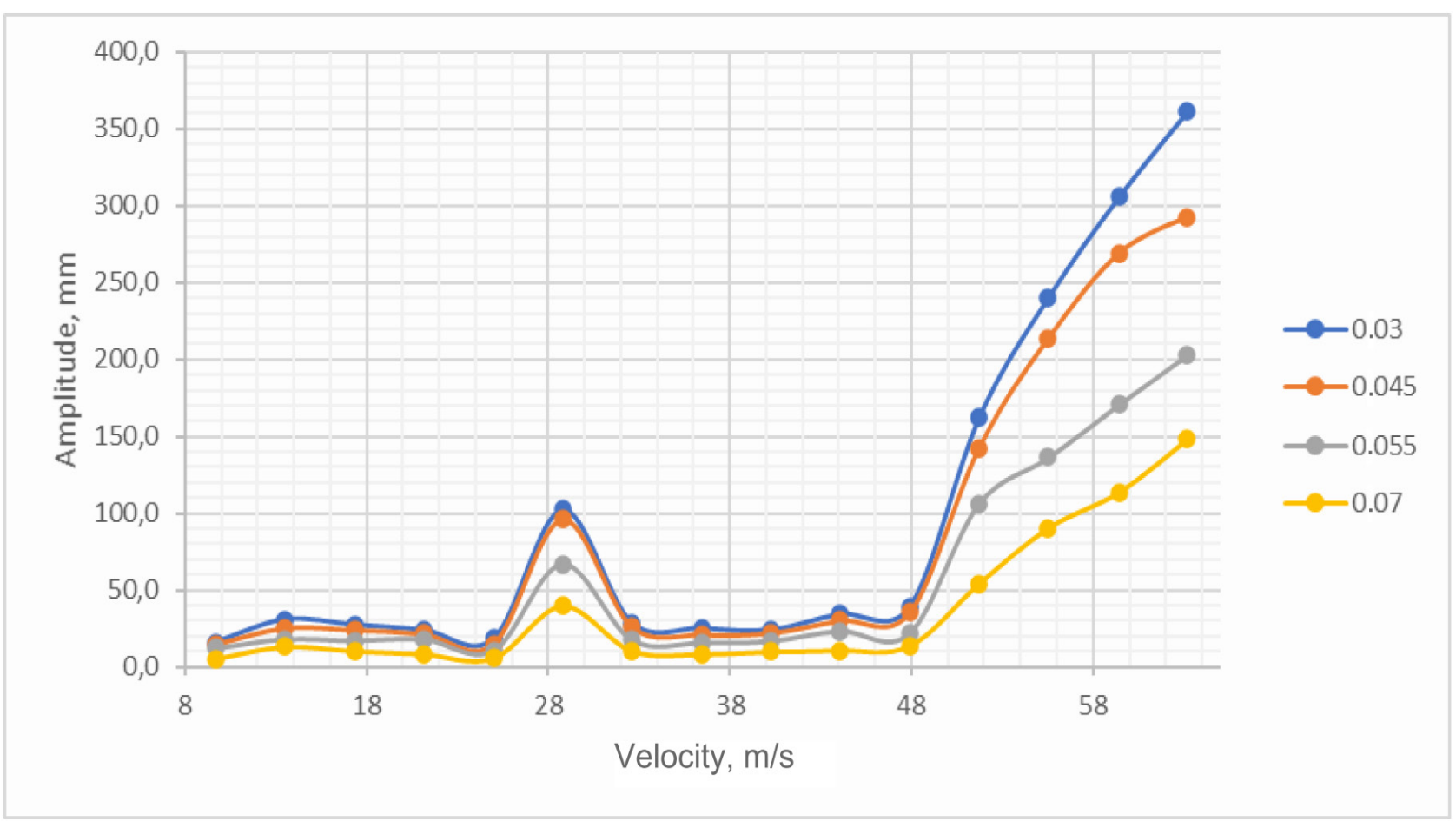

Figure 8. Oscillation amplitude's dependence on the wind flow velocity in the model at an angle of attack of $+3^{\circ}$

\section{Conclusions}

The results obtained show that, despite the general trend towards the decrease in the amplitude of bridge span structure oscillations as the structural damping level increases, the dependence between these parameters is nonlinear.
When increasing the aerodynamic stability of large-span bridge structures by means of increasing the structural damping level, it is necessary to make appropriate engineering calculations and thus determine the expected value of the oscillations' logarithmic decrement after making structural 
changes. We further recommend conducting additional experimental studies in a wind tunnel in order to assess the effectiveness of the solution selected.

Compliance with these requirements will help both to ensure the reliability and safety of bridge structures and to optimize the costs of increasing structural damping.

\section{Funding}

The work on making the models for experimental research as well as the analysis of Model No. 2 were carried out with the financial support of the Ministry of Science and Higher Education of the Russian Federation (Project \#FSWG-2020-0007: Theoretical and experimental design of new composite materials to ensure safety during the operation of buildings and structures under conditions of technogenic and biogenic threats). The analysis of Model No. 1 was supported by the Council on Grants of the President of the Russian Federation for State Support of Young Russian Scientists in the framework of Scientific Research MK-1403.2020.8. 


\section{References}

Ageev, N., Poddaeva, O., Churin, P. and Fedosova, A. (2021). Numerical simulation of the wind resonance of the bridge based on scale-resolving approaches. In: Balandin, D., Barkalov, K., Gergel, V. and Meyerov, I. (eds.) Mathematical Modeling and Supercomputer Technologies. MMST 2020. Communications in Computer and Information Science, Vol. 1413. Cham: Springer, pp. 93-104.

Argentini, T., Rocchi, D. and Somaschini, C. (2020). Effect of the low-frequency turbulence on the aeroelastic response of a long-span bridge in wind tunnel. Journal of Wind Engineering and Industrial Aerodynamics, Vol. 197, 104072. DOI: 10.1016/j.jweia.2019.104072.

Bas, S. and Catbas, N. (2021). Bridge failures and mitigation using monitoring technologies. In: Gülkan, P., Caner, A. and Memisoglu Apaydin, N. (eds.) Developments in International Bridge Engineering. Springer Tracts on Transportation and Traffic, Vol. 17. Cham: Springer, pp. 43-52.

Brownjohn, J. M. W. and Choi, C. C. (2001). Wind tunnel section model study of aeroelastic performance for Ting Kau Bridge Deck. Wind and Structures, Vol. 4, Issue 5, pp. 367-382. DOI: 10.12989/was.2001.4.5.367.

Cermak, J. E. (2003). Wind-tunnel development and trends in applications to civil engineering. Journal of Wind Engineering and Industrial Aerodynamics, Vol. 91, Issue 3, pp. 355-370. DOI: 10.1016/S0167-6105(02)00396-3.

Diana, G., Fiammenghi, G., Belloli, M. and Rocchi, D. (2013). Wind tunnel tests and numerical approach for long span bridges: the Messina bridge. Journal of Wind Engineering and Industrial Aerodynamics, Vol. 122, pp. 38-49. DOI: 10.1016/j.jweia.2013.07.012.

Diana, G. and Omarini, S. (2020). A non-linear method to compute the buffeting response of a bridge validation of the model through wind tunnel tests. Journal of Wind Engineering and Industrial Aerodynamics, Vol. 201, 104163. DOI: 10.1016/j.jweia.2020.104163.

Diana, G., Rocchi, D. and Belloli, M. (2015). Wind tunnel: a fundamental tool for long-span bridge design. Structure and Infrastructure Engineering, Vol. 11, Issue 4, pp. 533-555. DOI: 10.1080/15732479.2014.951860.

Highways England (2020). Highway structures and bridges. Design. Design rules for aerodynamic effects on bridges. DMRB Volume 1 Section 3 CD 363. Birmingham.

Kazakevich, M. I. (2021). Fundamentals of structural wind impact assessment. $2^{\text {nd }}$ edition. Moscow: Publishing House of the Moscow Institute of Civil Engineering - Moscow State University of Civil Engineering, $180 \mathrm{p}$.

$\mathrm{Li}, \mathrm{Y}$., Xu, X., Zhang, M. and Xu, Y. (2017). Wind tunnel test and numerical simulation of wind characteristics at a bridge site in mountainous terrain. Advances in Structural Engineering, Vol. 20, Issue 8, pp. 1223-1231. DOI: $10.1177 / 1369433216673377$.

Maystrenko, I. Y., Ovchinnikov I. I., Ovchinnikov, I. G. and Kokodeev, A. V. (2017). Failures and collapses of bridge constructions, analysis of their causes. Part 1. Russian Journal of Transport Engineering, Vol. 4, No. 4, 11.

Miyata, T., Yokoyama, K., Yasuda, M. and Hikami, Y. (1992). Akashi Kaikyo Bridge: Wind effects and full model wind tunnel tests. In: Larsen, A. (ed.) Aerodynamics of Large Bridges. London: Routledge, pp. 217-236. DOI: 10.1201/9781315136950-16.

Nagao, F., Utsunomiya, H., Oryu, T. and Manabe, S. (1993). Aerodynamic efficiency of triangular fairing on box girder bridge. Journal of Wind Engineering and Industrial Aerodynamics, Vol. 49, Issues 1-3, pp. 565-574. DOI: 10.1016/0167-6105(93)90050-X.

National Research Council of Italy. Advisory Committee on Technical Recommendations for Construction (2008). Guide for the assessment of wind actions and effects on structures. CNR-DT 207/2008. Roma

Poddaeva, O., Churin, P., Fedosova, A. and Truhanov, S. (2018). Investigation of the stability of a two-span bridge with the use of a high-precision laser displacement sensors. IOP Conference Series: Materials Science and Engineering, Vol. 317, 012020. DOI: 10.1088/1757-899X/317/1/012020.

Reinhold, T. A., Brinch, M. and Damsgaard, A. (1992). Wind tunnel tests for the Great Belt Link. In: Larsen, A. (ed.) Aerodynamics of Large Bridges. London: Routledge, pp. 255-267. DOI: 10.1201/9781315136950-19.

Solovyev, S. Yu. (2016). Aerodynamic stability of long-span bridges. Transport of the Russian Federation, No. 5 (66), pp. 47-50.

Tan, J.-S., Elbaz, K., Wang, Z.-F., Shen, J. S. and Chen, J. (2020). Lessons learnt from bridge collapse: A view of sustainable management. Sustainability, Vol. 12, Issue 3, 1205. DOI: 10.3390/su12031205.

Wardlaw, R. L. (1980). Sectional versus full model wind tunnel testing of bridge road decks. Proceedings of the Indian Academy of Sciences Section C: Engineering Sciences, Vol. 3, Part 3, pp. 177-198. DOI: 10.1007/BF02861559.

Wardlaw, R. L. (1992). The improvement of aerodynamic performance. In: Larsen, A. (ed.) Aerodynamics of Large Bridges. London: Routledge, pp. 59-70. 


\title{
АЭРОДИНАМИЧЕСКАЯ УСТОЙЧИВОСТЬ МОСТОВ С РАЗЛИЧНЫМИ УРОВНЯМИ СТРУКТУРНОГО ДЕМПФИРОВАНИЯ
}

\author{
Ольга Игоревна Поддаева*, Павел Сергеевич Чурин
}

Учебно-научно-производственная лаборатория по аэродинамическим и аэроакустическим испытаниям строительных конструкций, НИУ Московский Государственный Строительный Университет Ярославское шоссе, 26, Москва, Россия

*E-mail: poddaevaoi@gmail.com

\begin{abstract}
Аннотация
Конструкционное демпфирование является одним из наиболее важных параметров, влияющих на аэродинамическую устойчивость мостовых сооружений. Цель исследования: Оценка влияния конструкционного демпфирования мостовой конструкции на ее устойчивость в ветровом потоке. Методы: Экспериментальные исследования аэродинамической устойчивости типовых балочных мостовых сооружений (с двумя и четырьмя главными балками) с различными уровнями конструкционного демпфирования на базе Уникальной научной установки «Большая исследовательская градиентная аэродинамическая труба» НИУ МГСУ. Результаты: На основании результатов, проведенных экспериментальных исследований, установлено, что несмотря на общую тенденцию снижения амплитуды колебаний пролетного строения мостового сооружения с увеличением уровня конструкционного демпфрирования, зависимость этих параметров имеет нелинейный характер. При проведении научно-технического сопровождения проектирования реальных сооружений, в случае необходимости повышения аэродинамической устойчивости пролетного строения путем повышения уровня конструкционного демпфирования (изменение типа соединений конструкционных элементов, использование механических демпфирующих устройств), рекомендуется проведение экспериментальных исследований в аэродинамических трубах для оценки эффективности того или иного решения.
\end{abstract}

\section{Ключевые слова}

Мостовое сооружение, конструкционное демпфирование, аэродинамическая труба, экспериментальные исследования, секционная модель. 